DOI https://doi.org/10.36059/978-966-397-192-6/39-57

\title{
PART 3. \\ LIFE PATH AND SOCIO-POLITICAL ACTIVITY OF ANDREY SHEPTYTSKY
}

According to one of the researchers of the life and activity of Metropolitan Andrey Sheptytsky, Vasyl Laba, the Sheptytsky family was one of the oldest in Ukraine and originated (as evidenced by ancient letters) from the XIII century. ${ }^{118}$ A somewhat different point of view belongs to the contemporary historian J. Zaborovsky, who believes that the Sheptytsky family of the counts derived themselves from the Galician boyars of the fourteenth century and had a great church tradition. The scientist proved that only from the eighteenth century the family gave to the Ukrainian Church several abbots, bishops and two metropolitans: Lviv bishop Varlaam (171017I5), Athanasius - bishop of Lviv and Metropolitan of Kyiv (1715-1746), Athanasius - bishop of Przemysl (1762-1779), Lev - bishop of Lviv and Metropolitan Of Kyiv (1778-1779). In the middle of the XIX century this family encountered a fate, typical for the Ukrainian nobility: the transition to Roman Catholic rite and as a result - Polonization ${ }^{119}$.

On July 29, 1865 in the family of Earl Jan (Ivan) Sheptytsky and Sophia, a son was born to whom his parents gave at christening the triple name Roman Maria Olexandr. The Sheptytsky family lived in the village of Prylbych, near Yavoriv. Parents were not only highly educated, but also highly respected people of their time. His father, Ivan Sheptytsky (183619I2) was a Member of the Austrian Parliament and his mother - Sofia (1837-1904) - was a daughter of the famous Polish writer Fredr. The future Metropolitan owed much of his erudition to them. He was fluent in many foreign languages, including Latin, Hebrew, Greek. During one of his many trips abroad, in France he served a church service in French. By the way, Sofia Sheptytska was also fluent in English, German and French.

According to the researchers of his life and activity, Roman Maria Olexandr was marked with great piety from the very beginning, which was also a result of family upbringing. Since 1875 he began to take private lessons at home first, passing half-time exams at a Polish gymnasium in

\footnotetext{
118 Лаба Василь. Митрополит Андрей Шептицький. Його життя і заслуги. Люблин: Свічадо, 1990. С. 13.

119 Заборовський Я. Ю. Митрополит Андрей Шептицький. Нарис про життя i служіння народові (1865-1944 рр.). Івано-Франківськ, 1995. С. 6.
} 
Lviv. In the fall of 1879 he continued his education in Krakow at St. Anna Grammar School, where he was accepted to the fifth grade right away ${ }^{120}$. On June 11, 1883, Sheptytsky received a certificate of maturity, which testified to his excellent knowledge of school subjects. He served in the Austrian army for one year, but on June 22, 1884 he left it. There are different versions about the leaving of military service by Sheptytsky. In our opinion, it is necessary to agree with the opinion of J. Zaborovsky that the reason for this step was a disease of scarlet fever, which passed to the joints of the hands and feet ${ }^{121}$. The disease will progress, which will eventually lead to paralysis.

While still in military service, Sheptytsky studied at the Faculty of Law at the University of Krakow. After his resignation, he continued his studies first at Krakow and then at Breslav (Wroclaw) Universities (1883-1887). After graduating from them, on May 10, 1887, the future Metropolitan receives a Doctorate in Law. Thus, at first Roman Sheptytsky is only a secular person.

How did Sheptytsky decide to devote himself entirely to religion? This choice may have been influenced by a trip in 1886 to the Vatican, where he had a conversation with the Pope ${ }^{122}$. The mother of the future Metropolitan "immediately recorded the details of this memorable audience. When she told Cardinal Ledokhovsky and Macella about it, they immediately said: "This is truly a Providence". Leo XIII also did not forget about this visit and, as we shall see later, reminded about it eleven years later" ${ }^{\text {"123. Famous }}$ Russian philosopher Vladimir Solovyov and Ukrainian historian Volodymyr Antonovych made an important impact on this choise ${ }^{124}$. It is only known that in the same year Sheptytsky finally decided to enter the Basilian order. In the monastery he adopted the name Andrey. "Twelve letters from Andrey Sheptytsky" by Hryhir Meriam-Luzhnytsky, give the next explanation of the reason for this choice of the future Metropolitan: "Thanks to my uncles and You, Dear Mother, I understood what I am and what I should be: as a monk I ask for help from Uncle Varlaam, as archiereus I ask for help from Uncle Atanasius, and before the audience at the Caesarea or in the Apostolic Capital in Rome, I ask for help from Uncle Leo. When the moments of

120 Заборовський Я. Ю. Митрополит Андрей Шептицький. Нарис про життя i служіння народові (1865-1944 рр.). Івано-Франківськ, 1995. С. 8.

${ }^{121}$ Ibid.

${ }^{122}$ Королевський К. Названа праця. С. 57.

123 Ibid.

124 Заборовський С. Ю. В. Соловйов і А. Шептицький. Добрий пастир. 1990. С. 12-16. 
powerlessness come and I become a child, then I turn to You, Mom, and immediately I feel bigger and stronger...."125.

Already in 1896, Sheptytsky was appointed as an abbot at St. Onuphrius monastery in Lviv. And since this year Andrey did not limit himself only by monastic activity, but he goes "to the people", which later in time has brought him great fame and authority. On June 17, 1899 Sheptytsky was appointed as the Bishop of Stanislaw, and he was only 34 years old at that time. From the Pastoral Epistle to the Clergy, dated August 1, 1899, it is clear that Sheptytsky did not have a great desire to take up this important position: "...As soon as the news came to me that I should become a Bishop of Stanislaw, I defended myself against this government for a long time and did everything that I could to get rid of it" ${ }^{\prime 126}$. However, he also remained in this position for not a long time, because since October 21, 1900 Pope Leo XII named Andrey Sheptytsky Archbishop of Lviv and Metropolitan of Galicia.

Throughout his life Metropolitan Andrey repeated to his people that he required them to do three things: 1) to know their faith well, 2) to find out the faith of the Orthodox brothers, 3) to pray for unification. He also expected them to treat the Orthodox fairly and cordially. But he demanded the same attitude to the Ukrainian Greek Catholic Church from the Orthodox Ukrainians $^{127}$. In support of these words, A. Baran quotes A. Sheptytsky's message "To the Clergy": "Hierarchs in Ukrainian lands have been placed today in the same position as they were at the end of the sixteenth century (ie the Brest Union). If they want to solve the problems that the situation afflicts them with, for the sake of God and for the good of the Ukrainian people, they must so wisely investigate the condition of our Church as to comprehensively consider the consequences of the solution of hierarchs of the sixteenth century" 128 .

Metropolitan Andrey has done a great deal during his period of activity. First of all, he had to take care of upbringing the intelligent and educated priests. For this purpose, he sends talented young men to study in different countries of the world. In total, Andrey Sheptytsky gave way to the lives of about 200 religious figures. When Canadian Ukrainians asked him to

125 Дванадцять листів о. Андрея Шептицького до матері. С. 18.

126 Шептицький Андрей. Пастирські послання 1899-1914 pp. Т. I / Упорядники: Оксана Гайова, Роман Тереховський. Львів: Фундація «Андрей»; Видавничий відділ «Артос», 2007. С. 19.

${ }^{127}$ Баран О. Митрополит Андрей Шептицький і його екуменічні ідеї. Український Історик. 1-4 (120-123). Нью-Йорк - Торонто - Київ - Львів - Мюнхен, 1994. С. 187.

${ }_{128}$ Баран О. Митрополит Андрей Шептицький і його екуменічні ідеї. Украӥнський Історик. 1-4 (120-123). Нью-Йорк - Торонто - Київ - Львів - Мюнхен, 1994. С. 187. 
improve the liturgy, Metropolitan Andrey in 1902 sent to Canada three permanent Ukrainian priests from the Order of the Basilians, whom he placed near Edmonton. To make sure that such an act led to some qualitative changes, he made a trip to Canada in 1910, during which he visited a large part of territory from Montreal to Vancouver.

In his sermons, Metropolitan Andrey paid great attention to the education of the Ukrainian people in the tradition of Christian morality. Often he presented his ideas in written appeals to the people. There were more than a hundred of such appeals. He was the author of several dozen popular books. Everything Metropolitan did as a contributor, philanthropist and initiator of charitable actions is difficult even to list. He gave almost all his income to people's purposes. According to contemporary Ukrainian researchers Z. Sukhanova and N. Sulyma-Matlashenko, "there are many people living in Lviv today, who have used material assistance of Metropolitan at difficult times of their life" ${ }^{, 29}$.

With the arrival of the Imperial army in Lviv on September 6, 1914, Metropolitan was arrested and taken deep into Russia. An important role in his arrest was played by the fact that at the same time as the arrival of Russian troops, Sheptytsky made a call to the people to remain in their faith. Some historians mention that Sheptytsky's arrest has been linked to the fact that he actively worked for German secret services, although there is no cogent evidence ${ }^{130}$.

February Revolution of 1917 found him in Yaroslavl. One of the first orders by the head of the Provisional Government O. Kerensky (then the minister), was the order to release Sheptytsky. Although, it was not so easy to do that. In March 1917 Kerensky informed Sheptytsky that he could choose his own place of residence in Russia. Metropolitan decided to go to Petrograd. There, with the help of his acquaintances, he managed to obtain a request for the return of the personal archive, which had been confiscated earlier. The Provisional Government, at the insistence of Sheptytsky, allowed the legalization of the activities of the Greek Catholic Church in Russia, and appointed Exarch Leonid Fedorov as Metropolitan. But due to the difficult military situation, it was not easy to get to Galicia. Sheptytsky had to travel through neutral countries, "that's why Metropolitan's further road to his homeland ran through Stockholm. When crossing the Russian border in Finland, everything was taken away from him and from his companions, including even travel food. After Stockholm - Hamburg..., then

${ }^{129}$ Суханова 3., Сулима-Матлашенко Н. Андрей Шептицький: реалії хресного шляху. Сторінки історї̈ України ХХ століття. К.: Освіта, 1992. С. 325.

${ }^{130}$ Тополь М. Л. Виза на убивство. Военно-исторический журнал. 1990. № 11. С. 48-62. 
- Switzerland, Austria with the intention to get to Rome to meet Pope Benedict XV, but the trip to Rome did not take place at that time, because, while being a citizen of the Austro-Hungarian Empire, Metropolitan did not have access to Italy, who fought at side of the Entente, so on September 10, 1917, after three years of absence, A. Sheptytsky arrives to Lviv"131. One can only imagine how the inhabitants of Lviv met their Moses. There have been church services in his honour in many countries around the world.

On November 1, 1918 Metropolitan Andrey met a group of Sich Riflemen officers and blessed the formation of the Western Ukrainian People's Republic. However, on November 3, the situation changed and Sheptytsky was placed under house arrest. This was perhaps the greatest torment for him, a man, who accustomed to communicating with the people on a daily basis.

Following Galicia's accession to Poland as a result of the Saint-Germain Peace Treaty, Metropolitan Andrey continued to travel to different countries of the world. The purpose of these trips was to achieve unity among the Ukrainians, whose destiny was scattered all over the world. At that time, Galicia was under heavy social, national and cultural oppression, when the Polish government suppressed everything that was Ukrainian. Historical documents testify to this fact convincingly. Well-known Polish writer and publicist Zbigniew Zalouski wrote that in the former Eastern Galicia cultural and economic organizations were eliminated step by step, schools were closed. And in Volyn - where $80 \%$ of the population in the village were Ukrainian peasants - there were only 8 Ukrainian primary schools out of $2000^{132}$. However, as noted by Z. Zalouski, “...despite this, the polonization of the "local elements" was not successful. Under the influence of pressure, the process of national consciousness, especially in the countryside, was spreading. The army "tamed" troubled Ukrainian villages in the Ternopil voivodeship, shot peasant demonstrations in Volyn. In prisons, in the Bereha Kartuzska, the police mocked the arrested Ukrainians, and in response, the bullets of terrorists killed the Minister of Sanitation Government, the school curator, and innocent ordinary people. Tensions and animosity grew. The contempt of the ruling generates the hatred of the oppressed"133. The assimilationist policy of Poland in the Western Ukrainian lands first of all affected the state of public education. Under pressure from the Polish national democrats, the Sejm passed a law in 1924 about the transition of Ukrainian public schools into two languages. According to this law, history

131 Заборовський Я. Ю. Митрополит Андрей Шептицький. Нарис про життя i служіння народові (1865-1944 рр.). Івано-Франківськ, 1995. С. 29.

132 Залусский 3. Пути и достоверности. М., 1990. С. 269.

${ }^{133}$ Ibid. 
and geography in bilingual schools should been taught in Polish, and the study of Polish became compulsory. According to S. Kulchytsky's estimation, in 1921-1922 the number of Ukrainian and Polish public schools was almost equal in Eastern Galicia, about 2000 each. In 1937-1938 the number of Ukrainian schools decreased to 360; and instead - 2000 bilingual schools appeared. The number of Polish schools almost did not change. That is, bilingual schools were mostly organized on the basis of the Ukrainian ones ${ }^{134}$. The Polish authorities were outraged by Metropolitan's appeal to his people "Under the One Flag": "Hard times and coming black clouds make us unite more than ever before and, in truth, in our own strong unity, defend what we all know best... We will seek and defend social justice, the development of social protection of the peasantry, of the workforce, of all workers in general, and above all socially wronged"135. The Chairman of the Ukrainian People's Labor Party V. Okhrymovych protested against the capture of A. Sheptytsky by the Polish authorities ${ }^{136}$.

Ukrainian deputies to the Polish Sejm S. Baran, S. Bilak, D. Velikanovych, S. Vytwytsky and others repeatedly protested against the closure of the Ukrainian schools and against the prohibition of the official correspondence in the Ukrainian language, but their deputies' requests remained unresolved. The replies of the Sejm's Bureau Director A. Rutkowski were extremely vague and too general ${ }^{137}$. The Polish authorities systematically engaged in checking the loyalty of the Ukrainian population. Thus, on November 6, 1923 a school inspector, while inspecting a private school named after Shashkevych in Stanislaviv, concluded that Adolfina Makohon is unreliable in this institution. In his opinion, she was "the organizer of the groups of the Ukrainian pedagogical societies in Stanislaviv" and "was prone to antipanism"

On January 20, 1920 the Poles abolished the autonomous rights and selfgovernment of Galicia, thereby breaking their obligations to the Entente states to grant a Ukrainian national autonomy to the land. In fact, the Ukrainian school was under the authority of the Polish Ministry of Education. Ukrainian departments were closed at Lviv University, to which

134 Україна крізь віки: Т. 11. Кульчицький С. В. Україна між двома війнами (19211939 рр.). К.: Видавничий Дім «Альтернативи», 1999. С. 319.

${ }_{135}$ Митрополит Андрей Шептицький: Життя і Діяльність. Документи і матеріали. 1899-1944 / Упор. Оксана Гайова, Андрій Кравчук. Т. II. Церква і суспільне питання. Книга 2: листування / За ред. Андрія Кравчука. Львів: Видавництво отців василіан «Місіонер», 1999. С. 803.

${ }^{136}$ Ibid. C. 752.

137 Державний архів Івано-Франківської області (далі - ДАІФО). Ф. 2. Оп. 14. Спр. 2. Арк. 5.

${ }^{138}$ Ibid. Арк. 15, 16. 
Ukrainians responded by creating Lviv (secret) Ukrainian University (19211925), which had more than 50 departments and about 1500 students ${ }^{139}$.

The policy of denationalization led to resistance of the Ukrainians of Galicia. So, the district commander of Kolomyia complained to the local starosta that Petro Pavliuk, Mykola Zaikovsky, Mykhailo Ovzaruk, Mykola Huzol, Mykola Budziak (54 people in total) were conducting anti-Polish agitation in the school ${ }^{140}$. The Ukrainian pedagogical societies of Galicia were in a deplorable financial situation. One of the documents states that in order for the Kolomyia Society to operate fully, it is necessary to collect monthly taxes of 700 zloty's $^{141}$.

Authorities persecuted priests, who gave marriage certificates in Ukrainian. Thus, on November 22, 1924 the Stryi starosta Stefan Novak wrote to the Stanislaw Voivodeship that priest I. Karatnytsky "gave metrics in the Ukrainian language". Parson Anatol Barylevych also committed similar "crimes", when he wrote such testimonies to P. Kostiv and M. Bryndzey, he was forced to rewrite them within 14 days ${ }^{142}$.

In the 1930s, the situation of Galicia's Ukrainians deteriorated further. Metropolitan Andrey Sheptytsky was one of the first to rise to the defense of his people. He addressed his pastoral letter to the entire civilized world. The letter was published in the Transcarpathian newspaper "New Freedom" and became, to some extent, a constant topic for discussion. It said: "Around one hundred churches have been dismantled and destroyed. Some were burned by the hand of unknown criminals. Worship is prohibited in closed churches and chapels, both inside and outside them. There are precious ancient monuments of church architecture among the destroyed churches. The tools of religious worship are often destroyed. People were forced, sometimes by violence, to accept the Catholic faith in the Latin rite... Innocent people were repeatedly beaten and removed from their homes. It is not even free to teach catechism there and preach in the mother tongue of the people» ${ }^{143}$.

Speaking of the interwar period, it is necessary to agree with the assertion of modern historians that "in these circumstances, the UGCC, led by Metropolitan, was perhaps the only cementing force of the society, and its course on independence was, at least culturally and religiously, not only successful but also appropriate. It is a pity that the efforts of Metropolitan

\footnotetext{
${ }^{139}$ Жуковський А., Субтельний О. Нарис історії України. Львів, 1991. С. 107.

${ }^{140}$ ДАІФО. Ф. 8. Оп. 1. Спр. 123. Арк. 12.

${ }^{141}$ Ibid. Арк. 15.

${ }^{142}$ Ibid. Ф. 2. Оп. 1. Спр. 34. Арк. 1, 4, 13.

${ }^{143}$ Басараб В. І., Вегеш М. М. Життя і помисли митрополита Андрея Шептицького. Ужгород, 2003. С. 18.
} 
and the Church have not always been properly understood throughout society» $^{144}$.

Often there were contradictions between Sheptytsky's line and the methods of combating the Poles by the OUN. Metropolitan, indeed, has for a long time maintained close relations with organizations such as UNDO, OUN and other. And this fact was constantly used by the Soviet historians to attack Metropolitan. However, most of them forgot or did not want to notice, that it was Sheptytsky, who condemned the terrorist act of OUN members against Polish Minister Bronislaw Pieracki. Metropolitan understood that this would provoke new repression against the Ukrainian population of Galicia.

In September 1939 Soviet troops appeared in Lviv to occupy Western Ukraine under the Molotov-Ribbentrop Pact. Doctor of Medical Dentistry in Rochester, a Ukrainian by birth, Ivan Kindrat recalled: "In this situation the danger, at least the deportation, threatened to Dr. Panchyshyn, a deputy of the parliament and to our spiritual leader, Metropolitan Andrey Sheptytsky. So the OUN's rulers created and armed with rifles and grenades a student kurin (about 40 people) to defend them. I was in the group of 28 defenders of Metropolitan and his residence at St. George Cathedral. After barricading ourselves in the church and the residence, we waited... It is plausible that the NKVD did not have the time or the courage to attack us and so everything ended without a confrontation between us" 145 .

On September 17, 1939 Metropolitan of Galicia and Archbishop of Lviv Andrey Sheptytsky illegally convenes a church exarchs to hold a union action on the territory of USSR, informing the Vatican of his intentions postfactum. M. Charnetsky was appointed as a bishop in the lands of Volyn, Polissia, Chelm Land and Pidliashia. Metropolitan's brother Kasymyr Sheptytsky had to act in Russia and Siberia. Father Josyf Slipyi, the future successor of Bishop Andrey, received instructions for his missionary activity on the territory of the Dnieper Ukraine, and A. Nemantsevych had to go to Belarus. The occupation policy of the Third Reich in the East did not make it possible to carry out a united action in a legitimate way. During these processes A. Nemantsevych was arrested and subsequently shot. The same fate befell Metropolitan's brother.

The Bolsheviks behaved very audibly on the western Ukrainian lands. On October 25, 1939 in a note from the representatives of the Central Committee of the Communist Party of Ukraine to the secretary of the

144 Заборовський Я. Ю. Митрополит Андрей Шептицький. Нарис про життя i служіння народові (1865-1944рр.). Івано-Франківськ, 1995. С. 92.

${ }^{145}$ Культурне життя в Україні. Західні землі. Документи і матеріали. Т. 1. 1939-1953.

К.: Наукова думка, 1995. С. 61. 
Central Committee of the Communist Party of Ukraine M.O. Burmystenko, it was stated there that it was necessary to "immediately collect the tangibles from the private collections of Earl Dzieduszycki, Goluhowski, Borkowski and Sheptytsky (owners ran away, collections without care)" 146 into the Museum of Art Industry in Lviv and nationalize them. In a letter to Cardinal Eugene Tisserrant, Andrey Sheptytsky described the times of the first Soviet occupation as follows: “...It is a system completely devoid of anything that is or could be merciful, or even benevolent, even to the poorest. Everything that comes from the authorities seems to be aimed at diminishing, ruining, destroying and causing pain; with all that, it brings incredible clutter. Numerous new posts, bureaus, committees, representatives of all authorities in Moscow and Kyiv - and all those governments, that do not have a clear line, imagine that they are called to do everything and that they can do everything. All orders are threatened with death, every department of all these governments demands and always threatens death; it seems that all these workers can afford to kill anyone without the risk of being punished"147.

Andrey Sheptytsky repeatedly appealed to the Soviet officials with letters, asking for help and for loyalty to the Constitution, that was inforce in the USSR: "Although freedom of conscience is guaranteed by the Constitution, it is so interpreted in schools in Western Ukraine that the school binds the freedom of children, who want to pray before science, and who are being punished for prayer. And this should, in the eyes of parents and the whole community of Western Ukraine, diminish the authority of the Constitution, and it could prove in school, in some units, samples of deviation from the directional line, defined by the Constitution" "148. He even ventured to write a letter to J. Stalin: "Big mistakes made by the Soviet authorities in Western Ukraine, and the consequent state of the people entrusted to my pastoral care, compel me to appeal to your highest authority with such representation and supplication... The propaganda of godlessness in general, and especially in schools and among youths, is a great mistake of the Soviet authorities in our territory. First of all, it strikes and terrifies

\footnotetext{
${ }^{146}$ Культурне життя в Україні. Західні землі. Документи і матеріали. Т. 1. 1939-1953. К.: Наукова думка, 1995. С. 99.

147 Митрополит Андрей Шептицький: Життя і Діяльність. Документи і матеріали. 1899-1944 / Упор. Оксана Гайова, Андрій Кравчук. Т. II. Церква і суспільне питання. Книга 2: листування / За ред. Андрія Кравчука. Львів: Видавництво отців василіан «Місіонер», 1999. С. 892.

148 Митрополит Андрей Шептицький: Життя і Діяльність. Документи і матеріали. 1899-1944 / Упор. Оксана Гайова, Андрій Кравчук. Т. ІІ. Церква і суспільне питання. Книга 2: листування / За ред. Андрія Кравчука. Львів: Видавництво отців василіан «Місіонер», 1999. С. 901.
} 
people, who are attached to their faith as the most important part of the folk tradition, and it causes that people, and in a special way - the broad masses of the peasantry, do not have... (letter not completed - Aut.)"149. He also wrote a letter to the head of the Central Committee of the Communist Party of Ukraine N.S. Khrushchev about excessive taxation of the clergy and peasants ${ }^{150}$. In another letter to N.S. Khrushchev, A. Sheptytsky requested permission for priests to serve patients in hospitals ${ }^{151}$.

With the coming of the Red Army, persecution of the church and believers began, although the occupying power feared to oppose the UGCC openly. Atheistic propaganda began with the destruction of prayer houses and synagogues. So, in the city of Kovel of the Volyn region, according to the decision of mayor of the City Council, Pshenychny, two synagogues and one church were closed. The synagogue's property was transferred to the club of "Kharchoprom". In the city of Volodymyr-Volynsky the service in the synagogue was banned and a sewing workshop was organized. In the city of Dubno of the Rivne region, three synagogues and a church were banned, and their buildings were used for commercial institutions. Neglecting the thought of believers, there were confiscated prayer houses in the village of Lokachi of Volyn region, in the village of Vovnyche in Demydov district, Rivne region ${ }^{152}$.

According to the calculations of I. Andrukhiv, from September 1939 to July 1941, almost 400,000 people were detained and deported from the territory of Drohobych, Lviv, Stanislaw and Ternopil oblasts, of whom nearly 50,000 were executed before and during the first days of the war. Thus, almost every ninth inhabitant of the region has been repressed by the Soviet authorities. According to approximate calculations of some historians of the Russian Orthodox Church, 53 Orthodox priests were arrested in the former Polish territory, 10 of whom were later released, the fate of 37 is unknown, and six died or were shot ${ }^{153}$. A. Rusnachenko stated: "The control over the potentially hostile society was carried out by the Soviet authorities through three consecutive deportations of the population, first of all Polish. All members of the former civilian and military authorities, civil cervants, political and public figures and their families were a subject of deportation.

\footnotetext{
${ }^{149}$ Ibid. C. 903.

${ }^{150}$ Ibid. C. $910-911$.

${ }^{151}$ Ibid. C. 912.

152 Ярош Б.О. Сторінки політичної історії західноукраїнських земель (30 - 50-ті pp. ХХ ст.). Луцьк: Редакційно-видавничий відділ "Вежа" ВДУ ім. Л. Українки, 1999. С. 134.

${ }_{153}$ Андрухів І. Політика радянської влади у сфері релігії та конфесійне життя на Прикарпатті в 40-80-х роках XX століття: Історико-правовий аналіз. Івано-Франківськ: Лілея-НВ, 2006. С. 84-85.
} 
In general, almost every tenth inhabitant of the Western Ukraine has been the victim of repression, deportation, imprisonments and executions. The Soviet government in 1939-1941 repressed 3-4 times more people than the Nazi's on the twice smaller territory" 154 .

The attitude of the Soviet power to monasteries and monks was thoroughly investigated by M. Vuyanko: "With the coming of the Soviet power in Western Ukraine in 1939, new leadership tried to interfere with the normal life of the monastery (Stanislawiv Monastery of Basilian Sisters Aut.). Sad processes of interrogations, arrests and investigations began. Bolshevik officers made sure that the Sisters simply found themselves on the street, without any means of existence. Using long-standing personal relationships, Sisters have been searching privately for work, at risk of being exposed at any time. The Sisters went to live with acquaintances, relatives, and more often with strangers..."155. A parson from the village Voinyliv wrote in a letter to Metropolitan about the consequences for the parish of the resolution of the National Assembly of Western Ukraine on the nationalization of church and monastery lands: "After the arrival of the Red Army I experienced everything that other people did, succumbing to everything that could not be avoided! The land property was taken away leaving no stumps, but before that I had to witness the catastrophe of fire, that destroyed all the farm buildings on August 2, 1939 - it also burnt down all the gathering from the field, which had been taken by that time. As a result, the rest, along with the land, was taken away by the state, my possessor did not give me a year's rent, and left quite poor himself,"156.

In December 1939 Metropolitan Andrey consecrates Josyf Slipyi as a Bishop and appoints him as his successor. In Metropolitan's will of July 26, 1940, it was stated: "Yosyf Slipyi has been well known to the whole clergy of the Lviv Eparchy for years, because after 15 years as the rector of the Lviv Theological Seminary he has done great services for the whole Eparchy, and above all for the clergy and for all of you All. Fathers who, under his leadership, were brought up in the years from... The work, on which he had worked, sacrificing all those years, on God's leave lies in ruin, the bomb during the war destroyed completely the Church of St. Spirit,

154 Русначенко А. М. Народ збурений: Національно-визвольний рух в Україні й національні рухи опору в Білорусії, Литві, Латвії, Естонії у 1940-50-х роках. К.: Універсальне видавництво «Пульсари», 2002. С. 208.

${ }^{155}$ Вуянко М. Монастирі Івано-Франківська (Станиславова): перша половина XX ст. Івано-Франківськ: Нова Зоря, 1998. С. 47.

156 Митрополит Андрей Шептицький: Життя і Діяльність. Документи і матеріали. 1899-1944 / Упор. Оксана Гайова, Андрій Кравчук. Т. ІІ. Церква і суспільне питання. Книга 2: листування / За ред. Андрія Кравчука. Львів: Видавництво отців василіан «Місіонер», 1999. С. 917. 
valuable library of the Theological Society, which was kept with it, was also destroyed, the preeminent and precious seminary museum and the libraries of the Seminary and the Theological Academy were confiscated and transferred; museum - to the National museum, Library - to the university library. That total annihilation of his work was a heavy cross for Josyf, which he took with the help of Almighty and raised his soul..."157.

Josyf Slipyi became a reliable successor of Andrey Sheptytsky. An ardent supporter of catholicity, he has repeatedly stated: “...Ukrainian people, be yourself again. Get rid of your age-old ailment of strife and quarrels, of service to strangers, of seduction and humiliation, because to our shame they still are present in our national ecclesiastical leadership circles. Get rid of your age shortcomings, stand on your own feet in Ukraine and in the settlements!

...People, raise your head, straighten your hands!..." 158 .

By the proclamation of July 1, 1941 Metropolitan of Galicia congratulates the Wehrmacht, hoping that the German army would defeat Bolshevism: "By the will of the Almighty and Merciful God, in the Trinity of the One, a new era began in the life of the Cathedral Independent Ukraine. The People's Assembly, held yesterday, approved and proclaimed that historic event. In informing You, the Ukrainian People, of such listening to our prayers, I call You to show gratitude for the Almighty, faithfulness to His Church and obedience to the Authority... The Ukrainian people must show in that historical wave that they have a sufficient sense of authority, solidarity and vitality in order to earn a position among the peoples of Europe, in which he could develop his all God-given power. Prove through solidarity and conscientious fulfillment of responsibilities that you are ripe for the State Life» ${ }^{159}$. Sheptytsky put great hope in the wisdom of the new power: "We congratulate the victorious German Army as a liberator from the enemy. We give our obedience to the established Government. We recognize (we acknowledge - Aut.) Mr. Yaroslav Stetsko as a Chairman of the Regional Board of the Western Regions of Ukraine. We expect from the government, which He called to life, a wise, fair leadership over the citizens, which would coordinate the needs and good of all citizens, who are living in our land, regardless of what religion, nationality and social strata they belong to. God bless all Your works, Ukrainian people, and let Him give to

\footnotetext{
${ }^{157}$ Ibid.

158 Із слів патріарха Йосифа Сліпого. Альманах «Гомону Украӥни». Торонто, 1995. C. 77.

159 Шептицький Андрей. Пастирські послання 1939-1944 pp. Т. III / Упорядники: Оксана Гайова, Роман Тереховський. Львів: Фундація «Андрей»; Видавничий відділ «Артос», 2010. С. 114.
} 
all of our Leaders holy Wisdom from heaven"160. On July 5, 1941 Andrey Sheptytsky urges the believers and the clergy to meet Hitler's army favorably: "We congratulate with joy and gratitude the victorious German army, which has occupied almost the whole region, for liberation from the enemy... All those, who feel Ukrainians and want to work for the good of Ukraine, let them forget about any party strife, let them work in unity and agreement to restore our economic and cultural life destroyed so much by Bolsheviks. Then there is a hope in God that on the foundations of solidarity and hard work of all the Ukrainians a Cathedral Ukraine will rise not only as a great word and idea, but as a living, viable, healthy, powerful state organism, built by the sacrifice of the lives of some, and by anthill work, iron efforts and labor of the others" $"$.

In his famous Pastoral Message "Our Statehood", dated December 1941, Metropolitan convincingly states: "It is clear as the palm of your hand that the Native Hata (Ukrainian state - Aut.) will not appear, that there will be no Ukrainian monolith, when the Ukrainians-independents, between all the differences that divide them, will be not able to make as much unity as possible. This unity is necessary for Ukraine, and this need imposes on us all duties, and the whole future of the Motherland depends on the fulfillment of that obligation. If you want a nation-wide Hut with a deep and sincere wish, if that will is not just a phrase, an illusion, then it must be manifested by action, and that action must lead to unity. To unity in all directions..."

In December 1941 he was convinced that fascism was no different from Bolshevism and would condemn fascist ideology, which contradicted Christian morality. As we can see, Andrey Sheptytsky is quite cautious in his conclusions, since he condemns it only as a minister of the faith of Christ. And in early 1942 he would condemn fascism not only in terms of religion but also in terms of politics. There is no doubt that the fascists' elimination of the restoration of Ukrainian statehood on June 30, 1941, had the greatest impact on this.

Speaking against the fascist regimes' occupation, A. Sheptytsky put his personal life at risk. He repeatedly appealed to senior Nazi officials to protest against the persecution of the local population, including representatives of Polish and Jewish nationalities. Many facts are known when he was hiding people, persecuted by fascists. He was not arrested not only because he was very popular among his people, clergy, and in the

${ }^{160}$ Ibid.

161 Шептицький Андрей. Пастирські послання 1939-1944 pp. Т. III / Упорядники: Оксана Гайова, Роман Тереховський. Львів: Фундація «Андрей»; Видавничий відділ «Артос», 2010. С. 116.

162 Ibid. C. 147. 
church circles, but also because such an act could have led to a backlash from Ukrainian national forces, including OUN and UPA.

Concerning Andrey Sheptytsky's protection of the Jewish population of Eastern Galicia, let us allow ourselves to give a large enough, but necessary in our case, quotation from a book "Meetings and Conversations in Israel" of a well-known Ukrainian diaspora researcher, Dr. Peter Mirchuk: “...Ukrainian Metropolitan, alone in Europe at that time, in a separate letter to Hitler and Himmler, protested against the brutal persecution and extermination of the Jews, and subsequently at his residence in Lviv, in the dungeons of St. George Cathedral, saved the lives of a dozen rabbis with their families and commissioned all Ukrainian priests, monks, and nuns to help the Jews and save them from death.

Metropolitan Sheptytsky's heroic stance and his humanitarian action in favor of the Jews is widely known among the Jews themselves. Jewish scientist Leon Gayman... quotes Rabbi Dr. David Kagan as saying: "I swear to the Bible that Earl Sheptytsky was one of the greatest humanitarian philantropists in human history and the best friend of the Jews. I testify to this not only because he saved my life, my wife's and my child's life, and not only because he was able to save many other Jews from certain deaths at the hands of the Nazis. Please bear in mind not only what he did, but also the motives behind his actions. At that time Earl Sheptytsky was already an older man, physically infirm, but a giant spiritually. Over 80 years of age, paralyzed and on the eve of his death, he certainly did not seek any political benefits or respect for himself. It was all over him. If the German Nazis found the Jews in the dungeons of St. George Cathedral or in the monasteries, they would shoot or hang priests, monks or nuns on that same place, and burn down a church or monastery, or demolish and convert them into a stable for their horses. And if Metropolitan was willing to risk his own life, life of his priests, monks and nuns, he did so solely on the grounds of true, noble Christianity, friendly to the Jewish people and with a sense of national dignity" 163 .

The same opinion was expressed by Dr. Kurt Levin: "Israel has found few friends in critical moments of its history. The local population was usually indifferent to the fate of the Jews. Few sympathized and even fewer ventured to help. And in that hour of horror the Jews found a true friend in the person of His Excellency, Metropolitan Andrey Sheptytsky... Metropolitan's residence was a small baroque style ward near St. George Cathedral... The doors of Metropolitan's Residence were always open to

${ }^{163}$ Мірчук Петро. Зустрічі й розмови в Ізраїлю (Чи українці «традиційні антисеміти»). Нью-Йорк - Торонто - Львів: Союз українських полівязнів, 1982. С. 7-8. 
anyone who wished to visit Metropolitan. It happened often that a Jewish delegation from any town in the vicinity of Sheptitsky's area came here with a donation request for Jewish charitable or religious needs. In fact, in those localities many synagogues were built with a donated tree from Metropolitan Sheptytsky's forests...

The Jews thanked for this by their highest reverence and gratitude. As Metropolitan visited a city or a village, he was greeted by a large Ukrainian congregation, headed by Ukrainian priests and, necessarily, a rabbi... During the German occupation Metropolitan helped the Jews and hid them, and in the name of Christ called for such treatment towards the Jews from all the people of the Ukrainian Catholic Church. He issued a special Shepherd's Letter in the case of the Jews under the very eloquent headline: "Do not kill!". He went so far as to send a protest letter against the persecution of the Jews to the "Executioner of Europe" Himmler...",

Following the prohibition of the government of Yaroslav Stetsko, which arose as a result of the Act of June 30, 1941, in Lviv in February 1942 the Council of Seniors emerged, headed by former Member of the Parliament Kost Levytsky, whose moral leader was Andrey Sheptytsky. However, the Council of Seniors existed only until the end of the month ${ }^{165}$.

On November 9, 1943 Volodymyr Kubiyovych, Head of the Ukrainian Auxiliary Committee (UDK) and J. Pobihushchy, the captain of the division "Galicia", submitted into the newspaper "Lviv News" information about Metropolitan A. Sheptytsky's commitment to the formation of Ukrainian military units, including the mentioned division in the structure of Wehrmacht. Participation of three dioceses of the Galician province in the German-Ukrainian celebrations also testifies to this. Myroslav Maletsky recalled: "My destiny was decided by Metropolitan Andrey Sheptytsky, though it sounds audacious and strange on my side. The fact is that the underground of the OUN had ambiguous thoughts about the formation of the division. Some believed that the youth should go to the UPA, while others, on the contrary, believed that unarmed and untrained soldiers should go from the UPA to study in the division. There were also other thoughts.

Metropolitan Andrey Sheptytsky - a man of tremendous popularity and enormous authority - supported the idea of creating a Ukrainian division and said the prophetic words: "There is almost no price that should not be given for the creation of the Ukrainian army". It finally decided my fate and I went

164 Ibid. C. 8.

${ }^{165}$ Косик В. Україна і Німеччина у Другій світовій війні. Париж - Нью-Йорк - Львів, 1993. C. 177. 
to the division"166. Interesting in all respects is the book of memories of a former German officer of that division, Wolf-Dietrich Haike, who shared his thoughts on the internal climate in this military unit. "The Ukrainian soldiers," he wrote, "mostly volunteers, came from Galicia and rarely came from other Ukrainian lands. Most of them were a raw human material, with almost no military training, only rarely with military capabilities. Still, everyone wanted to become soldiers. Their age ranged from 16 to 70 years old, $90 \%$ from 18 to 30 years old... In Himmler's order to all the chiefs of staff from July 14, 1943, the next was said: when mentioning the Galician division, I forbid ever to speak of the Ukrainian division or Ukrainian nationality"167. However, the question of the fate of Galician Metropolitan and his congregation in these cases remains open. But it is a fact that before his death, Metropolitan Andrey called on the UPA to end the fight. In a conversation with the Head of the Department of History of Ukraine at Lviv State University, who at the same time was an agent of the NKVD, of which, of course, Sheptytsky did not know, Metropolitan said that he "had been fighting the UPA for two years, and in his messages he strongly condemned it" $" 168$.

In 1944 the Bolsheviks reappeared in Lviv. The eyewitness wrote: "The Bolshevik cavalry, moving towards us, was dirty, shabby and looked like an horde" 169 . The coming of the Soviet army in 1944 differed little from their coming in 1939. A. Sheptytsky had to conduct a moderate policy, seeking concessions from the new occupant. So, on August 29, 1944 he wrote a letter to the secretary of the Lviv Regional Committee of the Communist Party of Ukraine, I. Hrushetsky, asking him to allow the God's service in hospitals: "I ask to leave the churches with the Church Services in all the hospitals of Lviv region, in all city hospitals in Lviv and in the parish of the Medical Institute in Lviv"170. Grushetsky's answer was standard: "1.According to the Soviet constitution, the church is separated from the state. 2. There are Soviet laws in all Soviet institutions. 3. A hospital is a Soviet institution that applies Soviet laws accordingly. 4. Soviet medicine treats all citizens

166 Малецький М. «У моїй долі вирішальну роль відіграв митрополит Андрей Шептицький». Українська дивізія «Галичина»: історико-публічистичний збірник. Київ Торонто, 1994. С. 155.

${ }^{167}$ Гайке В.-Ф. Українська дивізія «Галисина». Тернопіль: Мандрівець, 2018. С. 25.

${ }^{168}$ Культурне життя в Україні. Західні землі. Документи і матеріали. Т. 1. 1939-1953.

К.: Наукова думка, 1995. С. 217.

169 Літопис нескореної України: Документи, матеріали, спогади. Книга 1 (Підготували Я. Лялька, П. Максимук, І. Патер та ін.). Авт. передмови Я. Лялька, Р. Бачинський. Львів: Просвіта, 1993. С. 250.

${ }^{170}$ Культурне життя в Україні. Західні землі. Документи і матеріали. Т. 1. 1939-1953. К.: Наукова думка, 1995. С. 200. 
regardless of their religious beliefs; the patient should receive help from our doctors. 5. Religion is a personal matter of every citizen of our country, which he or she may carry out at home or in appropriate religious institutions. 6. Nuns or Sisters of Charity, when they get a job in hospitals medical institutions - must obey the internal regulations of the hospital facilities" $" 171$.

In addition, Andrey Sheptytsky demanded that the "students of the Theological Seminary" should not be taken to the Red Army, and that the Soviet authorities should leave the printing press in the theological consistory ${ }^{172}$. In a letter to the Chairman of the Soviet People's Commissar of the UkrSSR M. Khrushchev, Hrushetsky wrote: "We believe that there should be a Soviet order in the Soviet hospital, and therefore the chapel should be closed... What about the conscription to the army of students of the Theological Seminary, we instructed the Military Commissariat to refrain from recruiting for a time, but we believe that they should be subject to the same rules as the Soviet students. The printing press has remained in the monastery so far, we ask for your permission to take it for the needs of the Executive Committee of the Regional Council of the Workers' Deputies and the Bureau of the Regional Communist Party"173. Hrushetsky asked to open a special committee in Lviv region, and to send to a permanent job there a "highly skilled specialist of the church issues at the Executive Committee of the Regional Council of Workers' Deputies"174, which was done soon.

The Bolsheviks made mass arrests against the local population. At St. George's Cathedral, they conducted searches and arrests among the students of the Theological Seminary, where Banderites and weapons were found ${ }^{175}$. The State Security Authorities, through their agents "Halytskyi" and "Vyshnyakov", have "established close supervision of Metropolitan". People's Commissar of the State Security of the UkrSSR Savchenko reported to M. Khrushchev that "in Sheptytsky's opinion, the arrests of the clergy of the Greek Catholic Church are the result of machinations of the Orthodox Patriarch in Moscow" ${ }^{\text {176 }}$. On September 17, 1944 Colonel Voloshchenko and Lieutenant Colonel Alekseev reported to the State Security Commissar Savchenko: “...Germanophile Sheptytsky was deeply disappointed with the

${ }^{171}$ Ibid. C. 237.

172 Ibid.

${ }^{173}$ Культурне життя в Україні. Західні землі. Документи і матеріали. Т. 1. 1939-1953.

К.: Наукова думка, 1995. С. 238.

${ }^{174}$ Ibid.

${ }^{175}$ Ibid. C. 265.

${ }^{176}$ Ibid. C. 266. 
Germans. On July 29, 1944 Metropolitan turned 79 years old, and he had a great reception for the clergy. Metropolitan, in his own words, expressed such an extreme optimism in his speech that he surprised the clergy: "Everything is in the hands of God," Metropolitan said, "and everything will end, without a doubt, very well" ${ }^{177}$. However, many reports from the NKVD authorities were of the opinion that such a sharp change in Sheptytsky's attitude to the new government was only a hidden dissatisfaction with the Bolsheviks.

They watched not only Sheptytsky, but also his supporters, who were later arrested and sentenced. Academicians of the UkrSSR Academy of Sciences Kolesa, Shchurat, Wozniak, who appeared in the operational reports of the NKVD as "Ukrainian bourgeois nationalists", were accused of a favorable attitude towards Sheptytsky. D. Manuilsky accused the composer Vasily Barvinsky: "You raised Sheptytsky on the shield, this Polish tycoon, who, by pulling on the lace, supported by the Vatican on the one hand, and by the nationalist circles on the other hand, carried out his reactionary, hostile to the people, policy, and you supported him, you raised him on a shield, and you did not have the courage now to speak to the youth, just to kneel down and say: "Judge us, we have fooled you, we have betrayed you, we are guilty, but we ask you to forgive us, we acknowledge our mistakes. Not everyone stated this"178.

Even after the death of Andrey Sheptytsky, the authorities forced Ukrainian writers to stain the light image of Metropolitan of Galicia. Thus, in a letter to the poet Petro Karmansky, the deputy editor-in-chief of the UkrSSR State Political Publishing House, G. Zatsepilin wrote: "We considered it necessary to supplement your manuscript a little with the materials about Sheptytsky, about his relations with nationalists, about the treacherous role of the Greek Catholic Church during the Patriotic War... If you consider it necessary to add something, then it can and should be done... If these facts outline any new aspects of the "activity" of the Vatican and its agents in the person of Sheptytsky and Uniate Church, then such additions certainly should be made"179.

However, all this will take place after the death of Metropolitan of Galicia. "On Wednesday, April 11, 1945, at about 8 o'clock in the evening the NKVD, in the force of about 600 people with three tanks, laid siege to St. George's Mountain, they got inside and began to "rage". From the Metropolitan Chapel it was taken more than 100 thousand rubles, intended

\footnotetext{
${ }^{177}$ Ibid. C. 217.

${ }^{178}$ Культурне життя в Україні. Західні землі. Документи і матеріали. Т. 1. 1939-1953.

К.: Наукова думка, 1995. С. 272-273.

${ }^{179}$ Ibid. C. 675-676.
} 
for the needs of the Metropolitan Ordinary, Theological Seminary and others. From the Metropolitan Office they took away all the ancient, as well as the modern, archive, all acts, etc. They took away everything else that belonged to it. Two cars of prayer books and other spiritual books were taken away, and the rest of the books and prayer books were thrown out, trampled and destroyed ${ }^{180}$. There were actions that are more immoral: "From St. George Cathedral they took away all the gold things, they left no tangibles. The audit was extremely brief and detailed. On Tuesday they broke the Ex' Metropolitan Sheptytsky's cellar in the pub. From there they took away a whole supply of wine, intended for the Church Services in the whole Galician Eparchy. The amount of wine exceeded 1600 liters. They took more than two hundred $\mathrm{kg}$ of candles. For two weeks they had been taking away all goods from the Metropolitan Chamber: Persian carpets, furniture, packed suitcases, packs... All the rooms, as well as the Metropolitan Chapel, were sealed and there was an inscription: "Do not pen the door, for breaking the seal - the punishment of death". Until now (June 25, 1945 - Aut.) the NKVD agents continue to manage there, and in the Metropolitan's bedroom the NKVD "sergeant" sleeps with an unmarried woman" 181 . But Metropolitan could not see this all. Andrey Sheptytsky died on November 1, 1944.

The church and political activities of Andrey Sheptytsky, closely intertwined, make it possible to evaluate his ideas, ideals and his actions of the universal significance, they can not be limited by only one single historical phenomenon or one nation. The most important values of the Christian-politician and the Christian of God's Church exist in his person.

180 Літопис нескореної України: Документи, матеріали, спогади. Книга 1 (Підготували Я. Лялька, П. Максимук, І. Патер та ін.). Авт. передмови Я. Лялька, Р. Бачинський. Львів: Просвіта, 1993. С. 251.

${ }^{181}$ Ibid. C. 254. 